\title{
Transcription of Children's Speech
}

\author{
Guest Editors \\ Yvonne Wren, Bristol \\ Sharynne McLeod, Bathurst, NSW \\ Sarah Verdon, Albury, NSW
}

6 figures and 18 tables, 2020 
S. Karger

Medical and Scientific Publishers

Basel $\cdot$ Freiburg $\cdot$ Hartford $\cdot$ Oxford

Bangkok $\cdot$ Dubai $\cdot$ Kuala Lumpur .

Melbourne $\cdot$ Mexico City .

Moscow $\cdot$ New Delhi $\cdot$ Paris ·

Shanghai $\cdot$ Tokyo
Disclaimer

The statements, opinions and data contained in this publication are solely those of the individual authors and contributors and not of the publisher and the editor(s). The appearance of advertisements in the journal is not a warranty, endorsement, or approval of the products or services advertised or of their effectiveness, quality or safety. The publisher and the editor(s) disclaim responsibility for any injury to persons or property resulting from any ideas, methods, instructions or products referred to in the content or advertisements.

Drug Dosage

The authors and the publisher have exerted every effort to ensure that drug selection and dosage set forth in this text are in accord with current recommendations and practice at the time of publication. However, in view of ongoing research, changes in government regulations, and the constant flow of information relating to drug therapy and drug reactions, the reader is urged to check the package insert for each drug for any change in indications and dosage and for added warnings and precautions. This is particularly important when the recommended agent is a new and/or infrequently employed drug.
All rights reserved.

No part of this publication may be translated into other languages, reproduced or utilized in any form or by any means, electronic or mechanical, including photocopying, recording microcopying, or by any information storage and retrieval system, without permission in writing from the publisher or in the case of photocopying, direct payment of a specified fee to the Copyright Clearance Center (see "General Information")

(c) Copyright $2019 / 20$ by S. Karger AG,

P.O. Box, CH-4009 Basel (Switzerland)

Printed on acid-free and non-aging paper (ISO 9706)

ISBN 978-3-318-06552-7

e-ISBN 978-3-318-06553-4

\section{KARGER}




\section{Folia Phoniatrica et Logopaedica}

\section{Contents}

Editorial

73 Transcription of Children's Speech

Wren, Y. (Bristol); McLeod, S. (Bathurst, NSW); Verdon, S. (Albury, NSW)

Review Article

75 Phonetic Transcription for Speech-Language Pathology in the 21st Century Stemberger, J.P.; Bernhardt, B.M. (Vancouver, BC)

Research Articles

84 An Alternative Approach to Measuring Reliability of Transcription in Children's Speech Samples: Extending the Concept of Near Functional Equivalence

Seifert, M.; Morgan, L.; Gibbin, S.; Wren, Y. (Bristol)

92 Transcription of Vietnamese Adults' and Children's Consonants by EnglishSpeaking Speech-Language Pathologists

Masso, S. (Bathurst, NSW/Lidcombe, NSW); McLeod, S.; Cronin, A. (Bathurst, NSW); Pham, B. (Bathurst, NSW/Hanoi)

108 Transcribing and Transforming: Towards Inclusive, Multilingual Child Speech Training for South African Speech-Language Therapy Students Pascoe, M.; Mahura, O.; Rossouw, K. (Cape Town)

120 The Impact of Real-Time Articulatory Information on Phonetic Transcription: Ultrasound-Aided Transcription in Cleft Lip and Palate Speech

Cleland, J. (Glasgow); Lloyd, S. (Glasgow/Edinburgh); Campbell, L.; Crampin, L. (Glasgow); Palo, J.-P. (Glasgow/Edinburgh); Sugden, E. (Glasgow); Wrench, A. (Edinburgh); Zharkova, N. (Newcastle)

131 Use of Transcription when Assessing Children's Speech: Australian SpeechLanguage Pathologists' Practices, Challenges, and Facilitators Nelson, T.L.; Mok, Z.; Ttofari Eecen, K. (Fitzroy, VIC)

143 Percent Consonant Correct as an Outcome Measure for Cleft Speech in an Intervention Study

Sell, D. (London); Sweeney, T. (Dublin)

152 Protocol for the Connected Speech Transcription of Children with Speech Disorders: An Example from Childhood Apraxia of Speech

Barrett, C.; McCabe, P.; Masso, S. (Sydney, NSW); Preston, J. (Syracuse, NY)

167 Author and Subject Index 